\title{
Bir Çizgi Film İncelemesi: “Mati ve Dada ile Sanat” Çizgi Filminin Okul Öncesi Sanat Etkinlikleri Kapsamında Gösteriminin Uygunluğu
}

\section{Nida ALTIPARMAK*, Çağla ÖNEREN ŞENDÍL** ve Gizem SOLMAZ***}

Öz: Bu araştırmada, Mati ve Dada ile Sanat çizgi filminin okul öncesi eğitim kurumlarındaki sanat etkinliklerinde sanatçı ve eserinin çocuğa tanıtılmasında kullanımının uygunluğunu belirlemek amaçlanmıştır. Bu çalışmada nitel bir araştırma yöntemi olan doküman incelemesi kullanılarak Mati ve Dada ile Sanat çizgi filminin gösterimde olan ve Türkçeye çevirisi yapılan 30 bölümü incelenmiştir. Çizgi filmin bölümleri bir değerlendirme formu hazırlanarak incelenmiş, ve araştırmada elde edilen veriler, içerik analizi yapılarak çözümlenmiştir. Yapılan analizler sonucunda elde edilen bulgular, çalışma için belirlenen biçimsel özellikler, sanat ve sanatçı, kültürel ögeler, gelişimsel uygunluk özellikleri ve verilen mesajlar doğrultusunda incelenmiştir. Çizgi filmin biçimsel özelliklerinin genel olarak çocukların gelişimsel seviyelerine uygun olduğu, çizgi filmde verilen bilgilerin çocuklar tarafından anlaşılması için ön bilgiye ihtiyaç duyulabileceği, sanat terminolojisi, sanatçının sanat tarzı hakkında bilgi vermesi ve sanatçının kullandığı farklı yöntemleri tanıttığı, ancak sınıfta bir öğretim materyali olarak kullanıldığında, öğretmenin yeni ortaya çıkan kelimeleri açıklayarak çocuklara destek olması gerektiği belirlenmiştir. Sanatçıların gerçek hayattaki dil ve aksanlarının, yaşadıkları dönemin giyim kuşam özellikleri ile birlikte çizgi filme yansıtılmış olduğu da dikkat çekmektedir. Mati ve Dada ile Sanat çizgi filminin okul öncesi eğitimi kapsamındaki sanat etkinliklerinde destekleyici bir unsur olabileceği ve öğretmenin paylaşacağı ön bilgiler yardımıyla sanat etkinlikleri kapsamında kullanılabileceği söylenebilir.

Anahtar Kelimeler: Okul öncesi dönem, Sanat eğitimi, Çizgi film, Teknoloji kullanımı.

\footnotetext{
*Araştırma Görevlisi, Niğde Ömer Halisdemir Üniversitesi, Eğitim Fakültesi, Temel Eğitim Bölümü, Email: nida.altiparmak@ohu.edu.tr, Orcid No: 0000-0003-4269-7507

${ }^{* *}$ Dr. Öğretim Üyesi, TED Üniversitesi, Eğitim Fakültesi, Temel Eğitim Bölümü, Email: cagla.sendil@tedu.edu.tr, Orcid No: 0000-0003-0622-4315

${ }^{* * *}$ Araştırma Görevlisi, Florida State University, Curriculum and Instruction, Email: gsolmaz@fsu.edu.tr,_Orcid No: 0000-0002-0560-2268
} 
An analysis of a Cartoon: Investigating the Appropriateness of “Art with Mati and Dada Cartoon” in the Context of Art Activities in Early Childhood

Abstract: In this study, the aim is to investigate the appropriateness of the cartoon named as "Art with Mati and Dada” with the purpose of introducing artists and their artifacts in early childhood art activities. Thirty (30) episodes of the cartoon were analyzed by using an evaluation form prepared by the researchers through engaging in content analysis method. Findings were evaluated based on the themes determined as art and artist, cultural elements, developmental appropriateness and messages given in the cartoon. Features related with format of the cartoon are found as appropriate for developmental stage of the children in early childhood period. However, children might need some prior knowledge to gain a full understanding of information presented in the cartoon. The cartoon introduces art terminology, art form and methods used, but when it is used as a teaching material, the teacher should support children by explaining unfamiliar words and concepts. Accents and clothing features of the era the artists lived were reflected well in the cartoon. Based on study findings, Art with Mati and Data cartoon can be used and might be a supportive element in early childhood art activities with the help of the prior information.

Keywords: Early childhood, Art education, Cartoon, Technology usage.

\section{Giriş}

Gelişen ve değişen teknoloji çağında, yaratıcılık ve üretkenlik bireylerin sahip olması gereken en önemli becerilerdendir. İnsanlığg geldiği noktaya taşıyan icatların, bireylerin küçük yaratıcılık damlalarının birleşiminin ürünü olduğunu düşünüldüğünde (Vygotsky, 2004), yaratıcılık ve üretkenliğin insanlığın gelişimindeki önemini kavranılabilir. Öğrencilerin iş yaşamında, vatandaşlıkta ve 21. yüzyıl sistemlerinde başarılı olması için gereken bilgi ve becerileri belirlemek amacıyla öğretmenler, uzman eğitimciler ve lider iş insanları tarafından belirlenen Framework for 21st Century Learning'de farklı kategorilerde 13 tane 21. yüzyıl becerisi yer alır (Partnership For 21st Century Skills, t.y). Yaratıcılık ve üretkenlik de bu maddeler içerisinde bulunmaktadır. Dolayısıyla, bu beceriler, 21. yüzyıl dünyasının ilerleyiş̧ine ayak uydurmak ve bu ilerleyişe katkı sağlamak için son derece gereklidir.

Yaratıcılık ve üretkenliğin bireyde gelişimi, erken çocukluk yıllarından itibaren başlar. Resnick’e (2007) göre, bir çocuğun yaratıcı düşünmeyi, sorunlara farklı yaklaşmayı öğrenerek büyümesi, kişisel ve profesyonel hayatı için her şeyden önemlidir. Piaget, bireyde yaratıcılığın gelişimini adaptasyon (uyum) süreci ile açıklamıştır. Yaratıcılığın ilk adımları özümseme ile 
başlar ve uyma ile devam eder ki bu bireyin çevre ile etkileşime girmesi demektir (AymanNolley, 1999). Bu yüzden, zengin çevre, çocukların yaratıcılığının gelişiminde önemli rol oynar. Benzer şekilde, Vygotsky’e (2004) göre, bireyin yaratıcılığı deneyimden beslenmektedir. Çocuklar oyun oynarken gerçek yaşam deneyimlerini oyunlarına yansıtmaktadırlar. Fakat bu deneyimleri direkt taklit etmekten öte, yaratıcılıkları ile harmanlayarak dışa vurmaktadırlar (Vygotsky, 2004). Yaratıcılığın gelişiminde deneyimin ve çevrenin önemli etkenler olması nedeniyle okul öncesi dönemde çocuklara uygun ortam, materyal ve fursat sağlanmalıdır. Milli Eğitim Bakanlığı Okul Öncesi Eğitim Programında Türkçe, Drama, Müzik, Oyun, Fen, Matematik, Okuma Yazmaya Hazırlık ve Sanat etkinliklerine yer verilmektedir (Milli Eğitim Bakanlığı [MEB], 2013). Ayrıca, öğrenme ortamı içerisinde Blok Merkezi, Kitap Merkezi, Müzik Merkezi, Fen Merkezi, Dramatik Oyun Merkezi ve Sanat Merkezi gibi öğrenme merkezleri bulunur (MEB, 2013). Bir bütün olarak öğrenme ortamı ve etkinlikler, çocukların yaratıcılık gelişiminin desteklenmesinde çok önemlidir. Sanat eğitimi özelinde bakacak olursak, çocukların estetik algılarını ve manipülatif becerilerini geliştirecek çeşitli materyallerle tanıştırılmaları; çeşitli deneyimlerinden beslenerek kendilerine özgü ürünler ortaya koymaya teşvik edilmeleri önerilmektedir (MEB, 2013).

Okul öncesinde sanat eğitiminin ilk adımları “Anaokullarının Babası” olarak anılan Alman Friedrick Froebel tarafindan atılmıştır. Froebel, çocukların yaratıcılıklarını, kağıt katlama, çizim, kil ile modelleme ve dikiş gibi "görevler" adını verdiği etkinliklerle desteklemiştir (Morrison, 2007). Abraham Maslow ise İhtiyaçlar Piramidi Teorisi'nde çocukların estetik çevreden zevk aldığına, bu yüzden öğrenme ortamının bitkiler, resim ve müzik ile estetik hale getirilmesi gerektiğine yer vermiştir (Morrison, 2007). Amerika'da önceleri matematik, dil etkinlikleri ile akademik öğrenmeyi desteklemeye daha fazla önem verilmekte, sanat etkinlikleri ise kimi eğitimciler tarafindan sonuç odaklı ve yetişkin tarafindan yönetilen etkinlikler olarak görülürken, kimi eğitimciler için ise süreç odaklı ve çocuğun istek ve ihtiyaçlarını dikkate alan etkinlikler olarak yer aldığı belirtilmektedir (McClure, Tarr, Thompson ve Eckhoff, 2017). Daha sonra NAEA (National Arts Education Association) tarafından yürütülen çalışmalar ile okul öncesinde sanat eğitiminin esasları oluşmaya başlamıştır (McClure ve ark., 2017). Bu esaslar, çocukların görsel sanatlar alanında gelişimi ve kendini ifade edebilmesi ile çocukların bu alanda nasıl desteklenebileceği hakkındadır. Bu esaslara göre, çocuklar organize edilmiş, materyal açısından zengin ve hayal dünyalarını destekleyecek bir ortama ve çocukların özel istek ve ihtiyaçlarına duyarlı, onları çok yönlü olarak destekleyen ve iyi gözlemleyen bir eğitimciye ihtiyaç duymaktadırlar (McClure ve ark., 
2017). İtalya'da Loris Malaguzzi öncülüğünde ortaya çıkan ve çocukların yüz dili olduğu düşüncesini benimseyen Reggio Emilia Yaklaşımına göre ise, sanat çocukların en önemli kendini ifade ediş biçimidir (Morrison, 2007).

Günümüzde, çocuklara deneyim kazandırarak, onların yaratıcılıklarını besleyecek uygulamalar yaygınlaşırken, çocukların öğrenme ortamında gerçek sanatçılarla ve onların sanat eserleriyle tanışmalarına yönelik çalışmalar da önem kazanmaktadır. Kıbrıs’ta bir okul öncesi kurumda yapılan üç aşamalı müze eğitimi projesi sayesinde çocukların; sanatçıların kullandığı materyaller ve sanat eserlerinin oluşum aşamalarıyla ilgili keşifler yaptıkları, aynı zamanda sanatın sadece resim yapmaktan ibaret olmadığını, farklı materyallerle de sanat yapılabildiğini öğrendikleri bulgusuna ulaşılmıştır (Trimis ve Savva, 2004). Ankara'da özel bir anaokulunda yapılan Çocuk-Sanatçı, Sanatçı-Çocuk Projesi'nde ise, çocukların bir sanatçı tarafından üretilen bir sanat eseri ile etkileşime geçmeleri sağlanmıştır (Acer, 2015). Proje öncesi ve sonrasında, çocuklara sanatçı ve sanat hakkında sorular sorulmuş ve çocukların proje sonrasında, öncesine göre çok daha detaylı cevaplar verebildikleri, sanat eserinin değeri hakkında farkındalık kazandıkları gözlemlenmiştir (Acer, 2015). Çocukların müzelerle, sanatçılarla ve sanat eserleriyle iç içe olmaları, onların farklı deneyimler elde etmelerini sağlayacak ve iç dünyalarını zenginleştirecektir.

Milli Eğitim Bakanlığı Okul Öncesi Eğitim Programı’nda, Sosyal Duygusal Gelişimle İlgili Kazanımlar, Göstergeleri ve Açıklamaları kısmında sanat eğitimi ile ilgili kazanımlara yer verilmiştir (MEB, 2013). Kazanımlar arasında çocuğun kendini yaratıcı ve özgün yollarla ifade etmesi için öğretmen tarafindan firsatlar yaratılması, çocukların farklı sanat dalları ile tanıştırılması, çevre olanakları dâhilinde müze, galeri ziyaretleri ve misafir sanatçı davetleri düzenlenmesi gerektiği belirtilmiştir. Diğer bir kazanımda çocukların kendi kültürünü ve diğer kültürleri tanıması, aradaki benzerlik ve farkları öğrenmesi gerektiğine vurgu yapılmıştır. Sanatın da kültürün bir öğesi olması dolayısıyla, bu kazanımın da sanat eğitimi ile ilgili olduğu düşünülebilir. Programda yer alan kazanım 14 ise doğrudan sanat eğitimi hakkındadır (MEB, 2013). Kazanım 14'e göre, çocuk sanat eserinin değerini fark etmeli, sanat eserinin özelliklerini gözlemleyebilmeli, farklı sanat dallarından haberdar olmalı, çocuğa sanat eseri hakkındaki düşüncelerini ifade etme imkânı sunulmalı ve çocuğun sanat eserinin değerini fark etmesi sağlanmalıdır. Çocuk, eser hakkındaki düşüncelerini ifade ettikten sonra eser ve onu üreten sanatçı hakkındaki bilgiler çocuğa verilmelidir (MEB, 2013). Bu maddeler ışığında söylenebilir ki, Okul Öncesi Eğitim Programında da, okul öncesi dönemde çocuğun sanat eserleriyle ve onları üreten sanatçılarla tanışmasına önem verilmektedir. 
Bununla birlikte, MEB'in öğrenme ortamlarında teknoloji kullanımını artırmaya yönelik yaptığı çalışmalardan yola çıkarak, eğitimde günümüz olanaklarının kullanımına önem verildiği söylenebilir. 2010 yılında Milli Eğitim Bakanlığı ve Ulaştırma Bakanlığının ortaklaşa çalışmasıyla başlatılan Fatih Projesi (Akgün, 2011) "eğitim ve öğretimde fırsat eşitliğini sağlamak ve okullarımızdaki teknolojiyi iyileştirmek amacıyla bilişim teknolojileri araçlarının öğrenme-öğretme sürecinde daha fazla duyu organına hitap edilecek şekilde, derslerde etkin kullanımı" amacı ile başlatılmıştır (MEB, t.y.). Eğitim Bilişim A ğı (EBA) ise öğretmen ve öğrencilerin, eğitimde teknoloji entegrasyonunu sağlamak, eğitim ile ilgili içerikleri, teknolojiden faydalanarak oluşturulan ve Yenilik ve Eğitim Teknolojileri Genel Müdürlüğü tarafından sunulan çevrimiçi bir eğitim platformudur (Yenilik ve Eğitim Teknolojileri Genel Müdürlüğü, 2020). Tüm bu araçların, eğitimde teknoloji kullanımının gereksinimi ortaya koyduğu söylenebilir.

Araştırma sonuçlarına bakıldığında, teknolojinin çocukların hayatındaki yeri ve eğitimde kullanımının önemi açıkça görülmektedir. Bu yüzden, eğitimde teknoloji kullanımı konusundaki araştırmaların, eğitimde teknolojiyi kullanıp, kullanmamak üzerine değil, teknolojinin eğitimde hangi yollarla kullanılacağı üzerine olması gerekir (Sayan, 2016). Günümüzde teknolojinin içine doğmuş olan çocukların uygun teknoloji kullanımını desteklemek önem taşımaktadır (Jukes, McCain ve Crockett, 2010; Kivunja, 2014) Teknolojideki yeniliklere, video kalitesindeki artış ve video paylaşım sitelerindeki gelişimlere paralel olarak çizgi filmler bir öğrenme ve öğretme aracı olarak kullanılmaya başlanmıştır (İbili ve Şahin, 2016). Cesur ve Paker'in (2007) yurdun çeşitli yerlerinde 454 ilkokul öğrencisi ile yaptığı çalışmaya göre, çocukların çizgi filmlere olan ilgisi 10 yaşına kadar devam etmektedir. Amerika'da okul öncesi dönem çocuklarla yapılan bir araştırmaya göre ise, çocuklar günlük ortalama iki saat televizyon ve video izlemektedir (Rideout, Vandewater ve Wartella, 2003). Aynı araştırmaya göre, araştırmaya katılan çocukların \%97'si izledikleri çizgi film karakterinin görselini üzerinde bulunduran ürünlere sahiptir. Öte yandan, çocukların genellikle çizgi filmin ana karakterini kendilerine rol model aldıkları ortaya koyan çalışmalar da mevcuttur (Akça ve Çilekçiler, 2019; Oruç, Tecim ve Özyürek, 2011). Çocukların hayatında bu denli yer kaplayan çizgi filmlerin eğitim amaçlı kullanımı da araştırmaya değer bir konudur.

Okul öncesi dönem çocuklarının eğitiminde kullanılacak çizgi filmin, okul öncesi dönem çocuklarının gelişimine uygun olması gerekmektedir. Görsel ve işitsel bir araç olarak olay ve durumları somut hale getiren çizgi film, işlem öncesi dönemdeki çocukların eğitiminde fark yaratabilecek bir araçtır. Çizgi filmlerdeki ses ve görüntü efektleri, ilginç karakterler ve bu 
karakterlerin heyecanlı maceraları çocukların ilgisini çekmekte ve onlar üzerinde önemli etkilere yol açmaktadır (Yağlı, 2013). İzledikleri çizgi filme göre çocukların sosyal davranışlarının olumlu-olumsuz yönde etkilendiği (Oyero ve Oyesomi, 2014) ortaya konulmuştur. Ayrıca, kişilerin, meslek gruplarının, toplumun farklı kesimlerinin çizgi filmlerdeki temsilinin çocukları etkilemesi ve birtakım yargılar oluşturmalarına sebep olması kaçınılmazdır. Güler ve Akman’ın (2006) çocukların bilim ve bilim insanına dair görüşlerini saptamayı amaçlayan çalışmalarında, çocukların bilim ve bilim insanına dair fikirlerinin medyada gördükleri ile şekillendiği bulgusuna ulaşılmıştır. Ayan ve Baş’ın (2015) ilkokul öğrencilerinin en çok tercih ettiği 10 çizgi filmdeki söz varlığg ile ilkokul öğrencilerinin kelime hazinelerini karşılaştırdıkları çalışmada, çizgi filmlerin ve öğrencilerin söz varlığının büyük oranda örtüştüğü ortaya çıkmış ve bundan yola çıkarak çizgi filmlerdeki söz varlığının, çocukların kelime hazinesini etkilediği sonucuna varılmıştır. Bu bağlamda çocuklar tarafından eğitim amaçlı olarak izlenecek çizgi filmlerin önce uzman yetişkinler tarafından birçok açıdan incelenmesi gerektiği düşünülmektedir.

Günümüz şartları göz önüne alındığında, sanat eğitimi de teknolojiden ayrı düşünülemez. Teknolojinin sanat etkinliklerine entegre edilmesi, öğrencilerin öğrenmesini, hayal güçlerini ve yaratıcılıklarını desteklemek için oldukça önemlidir (Black ve Browning, 2011). Yunanistan'da bilgi ve iletişim teknolojilerinin sanat eğitiminde kullanımı hakkında lise öğrencileri ile yapılan anket sonuçlarına göre, öğrenciler teknolojik aletleri sanat projelerinde kullanmak konusunda olumlu görüş bildirmiştir (Athanasiadis, Persa, Ilias ve Efstathios, 2011). Ayrıca, öğrencilerin çoğunluğu teknolojinin yeni sanat formları yaratmaya yardımcı olacağını düşünmektedir. Benzer şekilde İsveç’te bir devlet okulunda okuyan 13-15 yaş aralığındaki öğrenciler ve sanat öğretmenlerinden dijital medya araçlarının sanat eğitiminde kullanımı hakkında yapılan görüşme verilerine göre, öğrencilerin sanat eserlerini üretirken hem bilgisayar hem el ile çalışma seçeneklerine sahip olmalarının onlar için bir avantaj olduğu bulgusuna ulaşılmıştır (Marner, 2013). Ayrıca, bilgisayar ile çalışmak, hem istedikleri görüntüye ulaşabilmelerini, hem de zamandan tasarruf etmelerini sağlamaktadır. Bunun yanı sıra, okul öncesi dönemde sanat eğitiminde teknoloji kullanımı hakkında da çalışmalar mevcuttur. Terreni (2010) tarafından yapılan çalışmada, akıllı tahtaların okul öncesi dönem çocuklarının görsel sanatlar konusundaki yaratıcılıklarını destekleyebileceği sonucuna ulaşılmıştır. Arttırılmış gerçeklik uygulamaları da okul öncesi dönemde çocukların öğrenme deneyimlerini zenginleştirme potansiyeli taşıyan bir dijital araç olarak yerini almaktadır (Madanipour ve Cohrssen, 2020). Hong Kong’da 4-5 yaş aralığındaki 30 çocuk, sınıf öğretmeni, okul yöneticisi, 
bilgi ve iletişim teknolojileri öğretmeni ve 2 gönüllü ebeveyn ile sanat eğitiminde artırılmış gerçeklik kullanımını değerlendirme amaçlı bir araştırma yapılmıştır. Araştırmada, bu uygulamanın çocukların gelişimi açısından sorun teşkil edip etmeyeceğine dair soru işaretleri olduğu, diğer yandan da çocukların oldukça ilgisini çektiği ve öğretmenler tarafından soyut kavramların anlatımında ders materyali olarak kullanmanın faydalı olabileceği sonuçlarına yer verilmiştir (Huang, Li ve Fong, 2016). Tablet kullanımı ile ilişkili yapılan çalışmalarda ise, okul öncesi dönem çocuklarının tablet kullanımına oldukça hızlı uyum sağladıkları (Oliemat, 2018) ve düşüncelerini tablet üzerinde yaptıkları resimlerle yansıtabildikleri (Couse ve Chen, 2010), öğrenme aracı olarak tablet kullanımının öğrenme sürecini zenginleştirdiği (Pellerin, 2012), çocukların ilgi ve motivasyonlarını arttırdığı ortaya konulmuştur (Couse ve Chen, 2010). Tablet kullanımı; renklerin parlaklığı, firça temizleme gibi işler yapmayı gerektirmemesi, renklerin istenen şekilde karıştırılabilmesi gibi sebeplerle, çocuklar tarafından geleneksel çizim yöntemlerine tercih edilmiştir (Couse ve Chen, 2010).

Yapılan alan taraması neticesinde görülmüştür ki, okul öncesinde tablet kullanımı (Couse ve Chen, 2010; Oliemat, 2018; Pellerin, 2012), okul öncesi sanat eğitiminde ak1llı tahtaların kullanımı (Terreni, 2010) ve okul öncesi sanat eğitiminde artırılmış gerçeklik kullanımı (Huang ve ark., 2016) konularına ilişkin çeşitli çalışmalar bulunmaktadır. Ayrıca, alan yazında okul öncesi dönem çocuklarının çizgi filmlere olan ilgisi (Cesur ve Paker, 2007), okul öncesi dönemde çocukların çizgi filmler ile ne kadar zaman geçirdiği (Rideout ve ark., 2003), çizgi filmlerin çocukların sosyal davranışlarına etkisi (Oyero ve Oyesomi, 2014), çocukların çizgi film karakterlerini rol model alma durumları (Akça ve Çilekçiler, 2019; Oruç ve ark., 2011) ve izledikleri çizgi filmlerin çocukların söz varlığına etkisi (Ayan ve Baş, 2015) konularında da çalışmalar bulunmaktadır. Mevcut araştırmada ise okul öncesi dönemde sanat eğitiminde çizgi film kullanımı konusu ele alınmaktadır. Çocuklar, çizgi filmlerden ünlü sanatçılar ve onların sanat eserleri hakkında bilgi edinebilir, farklı sanat tarzları ile tanışabilir ve bu bilgiler 1şı̆̆ında daha yaratıcı ürünler ortaya koyabilirler. Bu sebeple, okul öncesi kurumlarda yapılan sanat etkinliklerinde, çocuklara sanatçı ve eserlerinin tanıtılmasında çizgi film kullanımının keyifli ve eğitici bir yol olacağı düşünülmektedir. Bu bağlamda, bu araştırmada "Mati ve Dada ile Sanat" çizgi filminin okul öncesi kurumlarda sanat etkinliklerinde sanatçı ve sanat eserini çocuklara tanıtma amaçlı kullanımının incelenmesi amaçlanmıştır. İçinde yaşadığımız teknoloji çağında üretken, çevresine duyarlı, estetik değerlere sahip ve yaratıcı bireyler yetiştirmek eğitimcilerin önde gelen hedefleri arasındadır. Bu bağlamda, araştırma sonuçlarının okul öncesi öğretmenlerine ve bu konuda çalışma yapan 
YYÜ Eğitim Fakültesi Dergisi (YYU Journal of Education Faculty), 2021;18(2)664-690,http://efdergi.yyu.edu.tr,

araştırmacılara 1şık tutacağı düşünülmektedir. Bu amaç doğrultusunda, araştırmanın alt soruları şu şekilde belirlenmiştir;

1) Mati ve Dada ile Sanat çizgi filminin biçimsel özellikleri nelerdir?

2) Mati ve Dada ile Sanat çizgi filmindeki sanatçı ve sanat özellikleri nelerdir?

3) Mati ve Dada ile Sanat çizgi filmindeki kültürel öğeler nelerdir?

4) Mati ve Dada ile Sanat çizgi filminin okul öncesi dönem çocukları için gelişimsel uygunluk özellikleri nelerdir?

5) Mati ve Dada ile Sanat çizgi filminde çocuklara ve öğretmenlere yönelik verilen mesajlar nelerdir? 


\section{Yöntem}

\section{Araştırmanın Deseni}

Mati ve Dada ile Sanat çizgi filminin okul öncesi kurumlarındaki sanat etkinliklerinde sanatçı ve eserinin çocuğa tanıtılmasında kullanımını incelemeyi amaçlayan bu çalışma betimseldir ve nitel araştırma yöntemi esas alınarak kurgulanmıştır. Araştırmanın metodu doküman incelemesidir. Dokümanlar, nitel araştırmalarda bilginin güvenirliliğini arttıran, araştırmanın kapsamını genişleten ve geçerliliğini arttıran önemli kaynaklardır. Belgeler ve yazıtların yanı sıra videolar, filmler ve fotoğraflar da doküman incelemesinin birer unsurudur (Yıldırım ve Şimşek, 2000). Yapılan bu araştırmada çizgi filmin videoları doküman analizinin kaynağı olarak kullanılmıştır.

\section{Çalışmanın Kapsamı}

Mati ve Dada ile Sanat çizgi filminin gösterimde olan 39 bölümü çalışmanın hedef evrenini, Türkçeye çevirisi yapılan 30 bölümü ise çalışmanın örneklemini oluşturmaktadır. Filmin bölümlerinden dokuz tanesine internet aracılığıyla ulaşılmış, diğer 21 tanesine ise "Da Vinci Learning” isimli televizyon kanalına ücretli abonelik aracılığıyla ulaşılıp tüm bölümler indirilerek arşivlenmiştir.

\section{Mati ve Dada ile sanat çizgi filmi.}

2012 yılında Giavanna Bo’nun yönetmenliğini yaptığı ve Gerard Lewis’in yazdığı çizgi filmlerin yayın süreleri 7:14 ile 8:00 dk. arasında değişmektedir. Videoların bir kısmına Youtube üzerinden ulaşılabilmekte, diğer kısmına ise Da Vinci Learning-Kids kanalından ücretli abonelik ile erişim sağlanabilmektedir. Çizgi filmin karakterlerinden "Mati”, sanata ilgi duyan meraklı bir kız çocuğudur. Ünlü sanatçılar hakkında kitaplar okur. Sanatçılarla tanışır ve onların sanat tarzına uygun eserler üretir. Her zaman kırmızı ressam şapkası takar. Çizgi filmin diğer bir karakteri olan "Dada", Mati'nin enerjik, sihirli arkadaşıdır. Yumurta şeklindedir ve her yere dönerek gider. Belindeki kemerde Kuartimetro adında ışınlama aleti vardır. Bu sayede sanatçıların yaşamış oldukları döneme 1şınlanarak sanatçı ve sanat eserini tanıma şansı elde etmektedirler. Dada’nın sağ gözünde bir teleskop takılıdır.

\section{Veri Toplama Aracının Hazırlanması ve Veri Toplanması}

Mati ve Dada ile Sanat çizgi filminin okul öncesi kurumlarındaki sanat etkinliklerinde sanatçı ve eserinin çocuğa tanıtılmasında kullanımının uygunluğunu belirlemek amacıyla öncelikle bir kontrol listesi- değerlendirme formu hazırlanmıştır. $\mathrm{Bu}$ formun hazırlanmasında şu aşamalar izlenmiştir: 
İlk olarak çalışma evreninin \%10’una denk gelen üç aynı çizgi film iki ayrı araştırmacı tarafından birbirinden bağımsız olarak izlenmiştir. Araştırmacılar tarafından çizgi filmdeki karakterler, sanatçı ve sanat dalı, teknikleri, kültür, olgu ve durumlar gibi konular ayrıntılı bir biçimde not edilmiştir. İki araştırmacının almış olduğu notlar bir araya gelip birlikte incelenmiş, birbiri ile aynı ve benzer olanlar birleştirilip kodlar oluşturulmuştur. Rastlantısal olarak seçilen bu üç bölümün içerik analizi yapılmış ve 30 bölümün verilerinin betimsel analizi yapılırken, ilk üç bölümün içerik analizi sonucunda hazırlanan kodlar temel alınmış ve izlenilen çizgi filmler buna göre değerlendirilmiştir. Değerlendirme yapılırken değerlendirme formu kullanılmıştır. İçerik analizi metin veya metinlerden oluşan bir bütün içindeki belli kelimelerin veya kavramların varlığını belirlemeye yönelik yapılan bir yöntemdir (Glesne, 2012). Betimsel analiz ise içerik analizi ile elde edilmiş olan temaların daha yüzeysel bir şekilde incelenmesi anlamına gelmektedir. Betimsel analizin asıl amacı, çalışmada elde edilen verileri düzenli ve anlaşılır bir şekilde sunmaktır. Verilerin yorumlanması yolu ile oluşturulur (Yıldırım ve Şimşek, 2000). Araştırmanın ilk bölümünde, izlenilen üç çizgi filmin analizinde tümevarımcı (verileri açıklayan kavram ve temalara ulaşılması), diğer 30 bölümü için ise tümden gelimci (önceden oluşturulmuş çerçeveye dayalı olarak verileri okuyup düzenlemek) bir yaklaşım izlenmiştir (Denzin ve Lincoln, 2005).

Nitel verilerin frekanslar şeklinde sunulması güvenirliği arttırarak yanlılığı azaltma yolunda önemli bir adımdır (Yıldırım ve Şimşek, 2000). Bu bağlamda, belirlenen kodların çizgi filmlerde ne sıklıkla bulunduğu ve bulunmanın kısmen mi tamamen mi olduğu da tablolar aracılığıyla verilmiştir. Kodları temsil edebileceği düşünülen kategoriler alan yazın taramasından gelen bilgiler 1şı̆̆ında belirlenmiştir. Kategoriler şu şekildedir: "biçimsel özellikler”, “sanatçı ve sanat”, "kültürel öğeler”, “gelişimsel özellikler” ve "verilen mesajlar”. Form hazırlandıktan sonra uzman görüşlerinin alınması amacıyla okul öncesinde sanat eğitimi, okul öncesi eğitimi ve çocuk medyası alanlarında doktora derecesine sahip üç uzman akademisyenin görüşlerine başvurulmuştur. Uzman görüşleri doğrultusunda, form yeniden düzenlenmiş, açıklık getirilmesi önerilen maddeler netleştirilmiş, tekrarı bulunan maddeler çıkarılıp daha kapsayıcı olduğu düşünülen maddeler eklenmiştir. Değerlendirme formunun son halinde 37 adet üç seçenekli (Evet-Hayır-Kısmen) soru bulunmaktadır. Evet seçeneği ilgili maddenin çizgi filmde var olduğu durumlarda, hayır seçeneği ilgili maddeye çizgi filmde rastlanmadığı durumlarda ve kısmen seçeneği ilgili maddenin çok yoğun bir şekilde gözlemlenmediği durumlarda kullanılmıştır. Hazırlanan bu form kullanılarak çizgi filmlerin Türkçe çevirisi bulunan 30 bölümü iki farklı araştırmacı tarafından değerlendirilmiştir. 
Araştırmanın güvenirliğini sağlamak amacıyla, izlenen çizgi filmler için gözlemciler arası güvenirlik çalışması yapılmıştır. Değerlendiriciler arası (Inter-rater) güvenilirliği tek bir formun iki uygulayıcı tarafından uygulanması ve aralarındaki korelasyona bakılması ile ölçülmektedir. $\mathrm{Bu}$ sayede iki araştırmacının uygulamasında ne kadar uyum olduğuna bakılmaktadır. Bu hesaplama, P (Uzlaşma Yüzdesi) $=[\mathrm{Na}$ (Görüş Birliği) / Na (Görüş Birliği) $+\mathrm{Nd}$ (Görüş Ayrılığı)] X 100 (Bakeman ve Gottman, 1997) formülü yardımı ile gerçekleştirilmiştir. Hesaplama sonucunda $\mathrm{P}=\%$ 98,0 değeri bulunmuş ve araştırma güvenilir olarak varsayılmıştır.

Çizgi filmlerin içeriklerinin incelendiği kontrol listesinde yer alan kodların frekans ve yüzdeleri bulgular kısmında verilmiştir. Elde edilen bulgular çerçevesinde yorumlama yapılmış ve elde edilen bulgular tablolaştırılarak sunulmuştur.

\section{Bulgular}

Mati ve Dada ile Sanat çizgi filminin okul öncesi kurumlarındaki sanat etkinlikleri kapsamında sanatçı ve eserinin çocuğa tanıtılmasında kullanımının uygunluğunun belirlenmesi amacıyla yapılan bu çalışmadan elde edilen bulgular araştırma sorularına paralel olarak verilmiştir.

\section{Mati ve Dada ile Sanat Çizgi Filminin Biçimsel Özellikleri:}

Araştırmanın birinci alt sorusunda Mati ve Dada ile Sanat çizgi filminin biçimsel özellikleri incelenmiştir. Toplam 30 çizgi filmin biçimsel özellikleri incelendiğinde, Tablo 1'de de gösterildiği üzere, çizgi filmde kullanılan dilde herhangi bir anlatım bozukluğu bulunmadığı ve aynı şekilde dilin telaffuz biçiminin de çocukların gelişimleri açısından uygun olduğu söylenebilir. Bunun yanı sıra, çoğunlukla çizgi filmde kullanılan cümlelerin açık ve anlaşılır olduğu ( $n=21)$ ve çizgi filmin süresinin $(n=20)$ sanatçı ve eseri hakkında yeterli ilgiyi aktarmak için de uygun olduğu söylenebilir.

Tablo 1. Mati ve Dada ile Sanat Çizgi Filminin Biçimsel Özellikleri

\begin{tabular}{|c|c|c|c|c|c|c|c|}
\hline & & \multicolumn{2}{|c|}{ Evet } & \multicolumn{2}{|c|}{ Hayır } & \multicolumn{2}{|c|}{ Kismen } \\
\hline & & $\mathbf{f}$ & $\%$ & $\mathbf{f}$ & $\%$ & f & $\%$ \\
\hline \multirow{5}{*}{$\begin{array}{l}\text { A-Biçimsel } \\
\text { Özellikler }\end{array}$} & Çizgi filmde kullanılan dilde anlatım bozukluğu vardır. & 0 & 0 & 30 & 100 & 0 & 0 \\
\hline & $\begin{array}{l}\text { Çizgi filmde kullanılan dilin telaffuz biçiminde hata } \\
\text { vardır. }\end{array}$ & 0 & 0 & 29 & 96.7 & 1 & 3.3 \\
\hline & $\begin{array}{l}\text { Çizgi filmde kullanılan kelimeler çocuğun günlük } \\
\text { hayatında duyabileceği türdendir. }\end{array}$ & 10 & 33.3 & 2 & 6.7 & 18 & 60 \\
\hline & $\begin{array}{l}\text { Çizgi filmde kullanılan cümleler açık ve anlaşılır } \\
\text { şekildedir. }\end{array}$ & 21 & 70 & 1 & 3.3 & 8 & 26.7 \\
\hline & $\begin{array}{l}\text { Çizgi filmin süresi sanatçı ve eseri hakkında yeterli } \\
\text { bilgiyi vermek için uygundur. }\end{array}$ & 20 & 66.7 & 3 & 10 & 7 & 23.3 \\
\hline
\end{tabular}




\section{Mati ve Dada ile Sanat Çizgi Filmindeki Sanatçı ve Sanat Özellikleri:}

Araştırmanın ikinci alt sorusunda Mati ve Dada ile Sanat çizgi filminde konu edilen sanatçı ve sanat özellikleri incelenmiştir. Toplam 30 çizgi filmde gösterilen sanatçı ve sanat özellikleri incelendiği zaman, Tablo 2'de belirtildiği üzere, çoğunlukla ( $n=19)$ çizgi filmde sanatçı ve sanat özellikleri hakkında verilen bilginin çocuk tarafından anlaşılması için ön bilgiye ihtiyacı olduğu düşünülmektedir. Örneğin, fotoğrafçı Berenice Abbott'un ve eserlerinin anlatıldığı bölümde "suda titreşen dalgaların fotoğraflanması”, “çoklu poz tekniği”, "stetoskop kullanarak hareketli bir cismi sabitmiş gibi gözlem yapıp üzerinde çalışmanı sağlayan pozlar” gibi kavramlardan bahsedilmektedir. Çizgi filmde sanatçı, kullandı̆̆ı tekniği anlatırken “kameranın gözü sadece gözlerimiz için görünmez olan gerçekliğin parçalarını görmelidir” gibi ifadeler kullanmıştır. Bu ifadelerin çocuk tarafından anlaşılabilmesi için ön bilgiye ihtiyaç olduğu düşünülmektedir.

Çizgi filmlerin tümünde $(n=30)$ yer alan sanatçının görsel imajı veya temsilinin sanatçının gerçek imajına benzemekte olduğu ve aynı şekilde çizgi filme konu edilen sanat eserinin görsel imajının da tüm çizgi filmlerde $(n=30)$ sanat eserinin orijinaline benzediği söylenebilir. Benzerlikleri örnekleyen görseller Şekil 1 ve 2'de sunulmuştur.

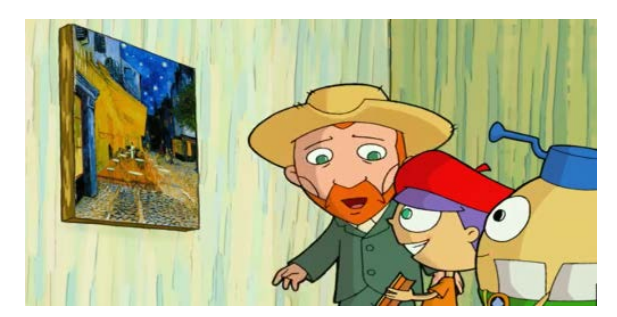

Şekil 1. Mati ve Dada ile Sanat Çizgi Filmindeki Sanatçı ve Eserinin Görsel İmajı (Van Gogh ve Teras Kafede Gece isimli eseri)
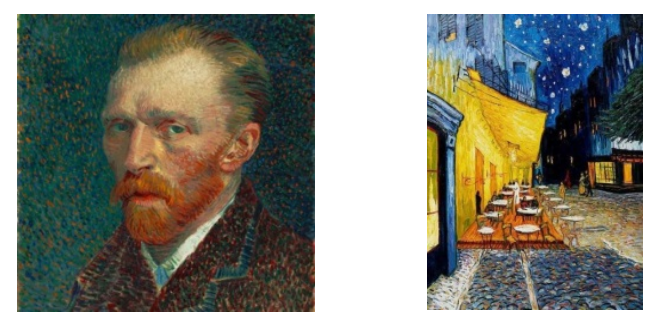

Şekil 2. Sanatçı ve Eserinin Gerçek Görsel İmajı (Van Gogh ve Teras Kafede Gece isimli eseri) (https://www.vincentvangogh.org/)

Bunun yanı sıra, çizgi filmlerinin birçoğunda $(n=22)$ sanat terminolojisinin kullanımına yer verildiği ve aynı zamanda da sanatçının sanat tarzı hakkında, çizgi filmlerin bir çoğunda da 
( $n=28)$ bilgilendirme yapıldığı görülmektedir. Örneğin, perspektif, portre, eskiz, senfoni, mozaik, rayograf, fresk, obscura kamera, veduta, natürmort gibi sanat terminolojilerine ve gelecekçilik, kübizm, izlenimcilik gibi sanat akımlarına yer verildiği belirlenmiştir. Sanat terminolojisi ve sanat tarzına yer vermenin yanı sıra, izlenen çizgi filmlerin birçoğunda ( $n=24)$, aynı zamanda sanatçının eserini oluştururken kullandığı yöntemler gösterilmiş ve anlatılmıştır. Örneğin ressam Jackson Pollock’un anlatıldığı bölümde sanatçının eserlerini oluştururken şövale kullanmadığını, resmi her açıdan çalışabilmesine olanak sağladığı için yerde resim yapmayı tercih ettiği, resimlerinde firça darbelerinin olmadığı, bunun yerine firçaları sopa gibi kullanıp boyaları tuvalin üzerine döktügünü, damlatarak veya püskürterek boyayı kullandığı, resim çizerken birtakım aletlerden faydalandığı (demir çubuk, çivi, vb.) gibi sanatçının sanat eserini oluştururken kullanmış olduğu yöntemler anlatılmakta ve gösterilmektedir.

Çizgi filmlerin hemen hemen yarısında $(n=14)$ sanatçının yaşadığı yerin-ülkenin özellikleri kısmen vurgulanmıştır ve yine aynı şekilde sanatçının yaşadığı yer ve eserleri arasında kısmen bağlantı kurulmuştur $(n=14)$. Örneğin, ressam Canaletto'nun anlatıldığ1 bölümde, sanatçının eseri olan Aziz Mark meydanı ve Venedik hakkında, Venedik'in mimari yapıları, sokakları, meydanları ve heykel figürleri hakkında da bilgilendirme yapılmaktadır. İzlenilen 30 çizgi filmin 24'ünde sanatçının eserleri çizgi filmde gösterilirken 6 tanesinde ise sanatçı eserlerine kısmen yer verilmiştir. Örneğin, Van Gogh'un Teras Kafede Gece, Zeytin Ağaçları, Auvers'deki Kilise ve Ayçiçekleri tablolarına yer verilirken, Mimar Sinan'ın gösterildiği bölümde sanatçının sanat eserlerinden sadece Mihrimah Sultan Camii gösterilmiş başka herhangi bir eserine yer verilmemiştir.

İzlenilen çizgi filmlerin \%86.7'sinde sanatçının yaşam koşullarına dair ipuçları kısmen verilmiştir. Örneğin, Van Gogh'un anlatıldığı bölümde sanatçı boya firçalarını düşürmüş ve Mati ve Dada onları bulup sanatçıya getirmiştir. Sanatçı boya firçalarının bulunmasına çok sevinmiş ve şu cümleyi kurmuştur: "Fırçalarımı kaybettiğimi düşünmüştüm, başka firça alacak gücüm yok, size bir ödül vermek istiyorum ancak hiç param yok, biraz ekmek ve peynir ister misiniz?” Daha sonra da çizgi filmin kahramanlarına peynir ve ekmek ikram etmiştir. Bu sahne ile Van Gogh'un yaşamakta olduğu yoksulluk hakkında kısmen ipuçları verilmeye çalışılmış olduğu düşünülmektedir. Yine aynı şekilde “Amedeo Amigliani” nin anlatıldığı bölümde sanatçı kafelerde yüzlerce insanın eskizlerini yaptığını ve bu eskizleri yemek ve içecek karşılığında vermekte olduğunu ifade etmiştir. Bu takasın sebebinin, sanatçıların çok çalışmalarına rağmen para kazanamamaları olduğunu ifade etmiştir. Bunun yanı sıra birçok 
çizgi filmde sanatçılar ev ortamında gösterilmektedirler. Bunun da dolaylı yoldan kısmen sanatçının yaşam koşullarına dair bir fikir verdiği söylenebilir.

Çizgi filmlerin \%60'ında sanatçının eserini oluştururken hissettiği duygulara yer verilmiştir. Örneğin Van Gogh'un anlatıldığı bölümde sanatçı eserlerinde renklerin parlaklığını anlatırken, eserlerini oluştururken oldukça heyecanlı hissettiğini ve bir başkasının da resme bakarken aynı duyguları hissetmesini istediğini ifade etmiştir. Yine aynı şekilde Leonardo Da Vinci'nin anlatıldığı bölümde sanatçı, etrafındaki dünyayı keşfetmek için içerisinde büyük bir arzu olduğunu, her şeye karşı merakı ve ilgisi olduğunu ifade etmektedir.

Çizgi filmlerin \%43.3'ünde farklı sanat dalları arasındaki bağlantıya yer verilirken \%23.3'ünde bağlantılara kısmen yer verilmiştir. Örneğin, "Henri de Toulouse-Lautrec”'in anlatıldığı bölümde dans ve resim arasında bağlantı kurulmuş ve dansçının resmini veya hareketini çizebilmek için dansı izlemek gerektiğine vurgu yapılmıştır. Yine aynı şekilde “Edgar Degas”'ın anlatıldığı bölümde bale ve resim arasında bir bağlantı yaratılmaya çalışıldığ1 söylenebilir. Diğer bağlantı kurulan sanat dalları müzik- resim ve fotoğraf-resimdir.

Tablo 2. Mati ve Dada ile Sanat Çizgi Filmindeki Sanatçı ve Sanat Özellikleri

\begin{tabular}{|c|c|c|c|c|c|c|c|}
\hline & & \multicolumn{2}{|c|}{ Evet } & \multicolumn{2}{|c|}{ Hayır } & \multicolumn{2}{|c|}{ Kismen } \\
\hline & & $f$ & $\%$ & $f$ & $\%$ & $f$ & $\%$ \\
\hline \multirow[t]{16}{*}{$\begin{array}{l}\text { B-Sanatçı } \\
\text { ve Sanat }\end{array}$} & $\begin{array}{l}\text { Çizgi filmde verilen bilginin çocuk tarafindan anlaşılması } \\
\text { için ön bilgiye ihtiyacı vardır. }\end{array}$ & 3 & 10 & 8 & 26.7 & 19 & 63.3 \\
\hline & $\begin{array}{l}\text { Çizgi filmde yer alan sanatçının görsel imajı veya temsili } \\
\text { sanatçının gerçek imajına benzemektedir. }\end{array}$ & 30 & 100 & 0 & 0 & 0 & 0 \\
\hline & $\begin{array}{l}\text { Çizgi filmde yer alan sanat eserinin görsel imaj1, sanat } \\
\text { eserinin orijinaline benzemektedir. }\end{array}$ & 30 & 100 & 0 & 0 & 0 & 0 \\
\hline & Çizgi filmde sanat terminolojisi kullanılmıştır. & 22 & 73.3 & 8 & 26.7 & 0 & 0 \\
\hline & Sanatçının sanat tarzı hakkında bilgi verilmiştir. & 28 & 93.3 & 0 & 0 & 2 & 6.7 \\
\hline & $\begin{array}{l}\text { Çizgi filmde sanatçının eserini oluştururken kullandığ } \\
\text { yöntemler gösterilmiş, anlatılmıştır. }\end{array}$ & 24 & 80 & 0 & 0 & 6 & 20 \\
\hline & $\begin{array}{l}\text { Çizgi filmde sanatçının yaşadığı yerin-ülkenin özellikleri } \\
\text { vurgulanmıştır. }\end{array}$ & 6 & 20 & 10 & 33 & 14 & 46.7 \\
\hline & $\begin{array}{l}\text { Çizgi filmde sanatçının yaşadığı yer ve eserleri arasında } \\
\text { bağlantı kurulmuştur. }\end{array}$ & 7 & 23.3 & 9 & 30 & 14 & 46.7 \\
\hline & $\begin{array}{l}\text { Çizgi filmde sanatçının yaşadığı dönemin özellikleri } \\
\text { vurgulanmıştır. }\end{array}$ & 3 & 10 & 9 & 30 & 18 & 60 \\
\hline & $\begin{array}{l}\text { Çizgi filmde sanatçının yaşadığı dönem ve eserleri arasında } \\
\text { bağlantı kurulmuştur. }\end{array}$ & 4 & 13.3 & 13 & 43.3 & 13 & 43.3 \\
\hline & Sanatçının eserleri çizgi filmde gösterilmiştir. & 24 & 80 & 0 & 0 & 6 & 20.0 \\
\hline & Sanatçının eserlerinin adlarına yer verilmiştir. & 15 & 50 & 10 & 33.3 & 5 & 16.7 \\
\hline & Sanatçının eserinin tipik özellikleri vurgulanmıştır. & 29 & 96.7 & 1 & 3.3 & 0 & 0 \\
\hline & $\begin{array}{l}\text { Çizgi filmde sanatçının yaşam koşullarına dair ipuçları } \\
\text { verilmiştir. }\end{array}$ & 2 & 6.7 & 2 & 6.7 & 26 & 86.7 \\
\hline & $\begin{array}{l}\text { Çizgi filmde sanatçının eserini oluştururken hissettiği } \\
\text { duygulara yer verilmiştir. }\end{array}$ & 18 & 60 & 1 & 3.3 & 11 & 36.7 \\
\hline & Farklı sanat dalları arasındaki bağlantıya yer verilmiştir. & 13 & 43.3 & 10 & 33.3 & 7 & 23.3 \\
\hline
\end{tabular}




\section{Mati ve Dada ile Sanat Çizgi Filmindeki Kültürel Öğeler:}

Araştırmanın üçüncü alt sorusunda Mati ve Dada ile Sanat çizgi filmindeki kültürel öğeler incelenmiştir. Toplam 30 çizgi film incelendiği zaman, Tablo 3’te gösterildiği üzere, çoğunlukla $(n=26)$ sanatçının yaşadığı dönemin giyim kuşam özelliklerinin çizgi filmde gösterilen sanatçının kıyafetinin çizimlerine yansıtıldığı görülmektedir. Örneğin Pantheon Tapınağının mimarı Apollodorus'un gösterildiği bölümde, sanatçının giyim ve kuşam özellikleri yaşadığı dönem hakkında ipuçları vermektedir (Şekil 3). Bunun yanı sıra, sanatçının yaşadığı yerde kullanılan dil/aksanın çizgi filmlerin \%5'inde sanatçının konuşmaları ile yansıtıldığı, \%26.7'sinde ise kısmen yansıtıldığı görülmektedir. Örneğin, Fransız sanatçı Edgar Degas'ın anlatıldığı bölümde, “merci”, “monşer” gibi kelimeler kullanılmış ve kullanılan dil aksanlı bir konuşma ile filme yansıtılmıştır. Yine aynı şekilde Fransız sanatçı "Henri de Toulouse-Lautrec”'in anlatıldığı bölümde “Bonjour Mösyö” gibi ifadeler aksanlı bir konuşma şekli ile kullanılmıştır.

Bunun yanı sıra, çizgi filmlerin \%66.7'sinde, filme yansitılan kültürel öğeler ile çocuğun kendi yaşamı arasında bağlantı kurması mümkün olma durumunun kısmen olduğu düşünülmektedir. Fakat çizgi filmlerin \%36.7’sinin çocukta farklı kültürler hakkında farkındalık yarattığı düşünülürken, \%30'unun da böyle bir farkındalık yaratma anlamında zayıf olduğu görülmektedir.

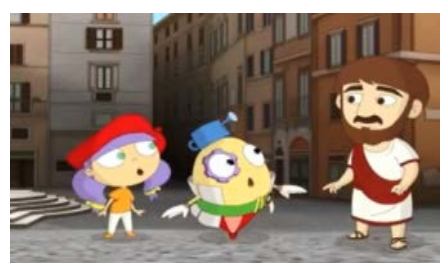

Şekil 3. Pantheon Tapınağının Mimarı Apollodorus'un Çizgi Filmdeki Görsel İmajı

Tablo 3. Mati ve Dada ile Sanat Çizgi Filmindeki Kültürel Öğeler

\begin{tabular}{|c|c|c|c|c|c|c|c|}
\hline & & \multicolumn{2}{|c|}{ Evet } & \multicolumn{2}{|c|}{ Hayır } & \multicolumn{2}{|c|}{ Kismen } \\
\hline & & $f$ & $\%$ & $f$ & $\%$ & $f$ & $\%$ \\
\hline \multirow[t]{4}{*}{$\begin{array}{l}\text { C.Kültürrel } \\
\text { Öğeler }\end{array}$} & $\begin{array}{l}\text { Sanatçının yaşadığı yerde kullanılan dil/aksan çizgi } \\
\text { filme sanatçının konuşmaları ile yansıtılmıştır. }\end{array}$ & 5 & 17.7 & 17 & 56.7 & 8 & 26.7 \\
\hline & $\begin{array}{l}\text { Sanatçının yaşadığı dönemin giyim kuşam özellikleri } \\
\text { çizgi filmde sanatçının kıyafetinin çizimlerine } \\
\text { yansıtılmıştır. }\end{array}$ & 26 & 86.7 & 0 & 0 & 4 & 13.3 \\
\hline & $\begin{array}{l}\text { Çizgi filme yansıtılan kültürel ögeler ile çocuğun kendi } \\
\text { yaşamı arasında bağlantı kurması mümkündür. }\end{array}$ & 4 & 13.3 & 6 & 20 & 20 & 66.7 \\
\hline & $\begin{array}{l}\text { Çizgi film çocukta farklı kültürler hakkında farkındalık } \\
\text { yaratır. }\end{array}$ & 11 & 36.7 & 9 & 30 & 10 & 33.3 \\
\hline
\end{tabular}




\section{Mati ve Dada ile Sanat çizgi filminin okul öncesi dönem çocukları için gelişimsel uygunluk özellikleri:}

Araştırmanın dördüncü alt sorusunda Mati ve Dada ile Sanat çizgi filminin okul öncesi dönem için gelişimsel uygunluk özellikleri incelenmiştir. Toplam 30 çizgi film, bu bağlamda incelendiği zaman, Tablo 4'te belirtildiği üzere, filmlerin \%33.3'ünde ( $\mathrm{n}=16)$ çocuğun kendi hayatı ile bağlantı kurması mümkün olmayan durumların varlığı belirlenmişken \% 53.3'ünde ise bu durumun kısmen yer aldığı dikkat çekmektedir. Buna paralel olarak, çizgi filmlerin yarısında ( $n=15)$ soyut kavramlar, hikayeler ve/veya kelimeler bulunmaktadır. Örneğin, Man Ray’ın anlatıldığı bölümde, fotoğrafı bir 1şık topuna benzeterek tasvir yapılması soyut bir tanımlama teşkil edebilir. Yine aynı şekilde ressam Rene Magritte ve Jackson Pollock'un anlatıldığı bölümlerde sanat eserinin içerisine girilmesi ve orada hareket ediyormuş gibi gösterilmesi ile ressam Paul Klee'nin anlatıldığı bölümlerde çizilen çizgilerin canlanması gibi durumlar soyut hikayelere örnek olarak verilebilir.

İzlenilen filmlerin yayın süreleri 7:14 ile 8:00 dakika arasında değişmektedir. $\mathrm{Bu}$ anlamda, izlenilen çizgi filmlerin büyük bir çoğunluğunun $(n=28)$ süresi okul öncesi dönem çocuklarının dikkat süreleri göz önüne alındığında uygun olduğu söylenebilir. Bunun yanı sıra, filmlerde şiddet içerikli sahnelerin $(\mathrm{n}=28)$ ve karakterler arası olumsuz diyalogların da yer almadığı (n=27) dikkat çekmektedir. Çizgi filmlerin çoğunlukla (n=22) olaylar-durumlar arasında neden-sonuç ilişkisi kurmalarını desteklediği ve yine benzer şekilde, birçoğunun $(n=20)$ çocuğun sözcük dağarcığını geliştirme potansiyeli olduğunu da göstermektedir.

Tablo 4. Mati ve Dada ile Sanat Çizgi Filminin Okul Öncesi Dönem için Gelişimsel Uygunluk Özellikleri

\begin{tabular}{|c|c|c|c|c|c|c|c|}
\hline & & \multicolumn{2}{|c|}{ Evet } & \multicolumn{2}{|c|}{ Hayır } & \multicolumn{2}{|c|}{ Kismen } \\
\hline & & $f$ & $\%$ & $f$ & $\%$ & $f$ & $\%$ \\
\hline \multirow[t]{7}{*}{$\begin{array}{l}\text { D-Gelişimsel } \\
\text { Uygunluk }\end{array}$} & $\begin{array}{l}\text { Çizgi filmde çocuğun kendi hayatı ile bağlantı kurması } \\
\text { mümkün olmayan durumlar mevcuttur. }\end{array}$ & 10 & 33.3 & 4 & 13.3 & 16 & 53.3 \\
\hline & $\begin{array}{l}\text { Çizgi filmde soyut kavramlar, hikayeler ve/veya } \\
\text { kelimeler bulunmaktadır. }\end{array}$ & 7 & 23.3 & 8 & 26.7 & 15 & 50 \\
\hline & $\begin{array}{l}\text { Çizgi filmin süresi okul öncesi dönem çocuklarının } \\
\text { dikkat süreleri düşünüldüğünde uygundur. }\end{array}$ & 28 & 93.3 & 0 & 0 & 2 & 6.7 \\
\hline & Çizgi filmde şiddet içerikli sahneler bulunmaktadır. & 0 & 0 & 28 & 93.3 & 2 & 6.7 \\
\hline & $\begin{array}{l}\text { Çizgi filmde karakterler arasında geçen olumsuz } \\
\text { diyaloglar (kavga, aşağılama, argo kelimeler) } \\
\text { bulunmaktadır. }\end{array}$ & 1 & 3.3 & 27 & 90 & 2 & 6.7 \\
\hline & $\begin{array}{l}\text { Çizgi film çocukların olaylar-durumlar arasında neden- } \\
\text { sonuç ilişkisi kurmalarını destekler. }\end{array}$ & 22 & 73.3 & 0 & 0 & 8 & 26.7 \\
\hline & Çizgi film, çocuğun sözcük dağarcığını geliştirir. & 20 & 66.7 & 0 & 0 & 10 & 33.3 \\
\hline
\end{tabular}




\section{Mati ve Dada ile Sanat Çizgi Filminde Çocuklara ve Öğretmenlere Yönelik Verilen Mesajlar:}

Araştırmanın beşinci alt sorusunda Mati ve Dada ile Sanat çizgi filminde çocuklara ve öğretmenlere yönelik verilen mesajlar incelenmiştir. Tablo 5'te belirtildiği üzere, toplam 30 çizgi film incelendiği zaman, çizgi filmlerin hiçbirinde öğretmenlere yönelik doğrudan veya dolaylı herhangi bir mesaj verildiğine rastlanmamıştır. Genel olarak karakterler arası diyaloglarda doğrudan mesajlara \%66.7 oranında kısmen yer verildiğini dolaylı mesajlara ise çoğunlukla kısmen yer verildiği görülmektedir. Çizgi filmde çocukların kendilerini sanat alanında geliştirmeleri konusunda da mesajlar bulunduğu ve bu mesajlara da kısmen yer verildiği söylenebilir.

Leonardo Da Vinci'nin anlatıldığg bölümde gözlemlemek, soru sormak ve harekete geçmenin bir şeyleri daha iyi görebilmenin ve öğrenmenin anahtarı olduğuna vurgu yapılması verilen mesajlara örnek olarak gösterilebilir. Benzer şekilde, Mimar Sinan’ın anlatıldığı bölümde, dünyada görünebilen ve görünemeyen güzelliklerin olduğu, güzelliğin andan ana bile değişebildiği, dışarıdan görünen ile içeriden görünenin aynı olmadığı, dışarıdan sade ve sert görünmesine rağmen farklı bir açıdan bakıldığında güzel ve parlak görünebildiğini Mihrimah Sultan Camii isimli eserinden örneklemeler yaparak anlatmaktadır. Bunun yanı sıra, Horiu-Ji Tapınağının anlatıldığı bölümde ise doğaya saygılı eserlerin inşa edilmesi gerektiğine yönelik mesajlar verilmeye çalışılmıştır. Diego Velazguez'in anlatıldığı bölümde ise görünen şeyin perspektifle ilgili olduğu, yerini değişmenin perspektifi değiştirebileceği, her insanın gördüğü şeyin çok farklı olabildiğine vurgu yapılarak sanat eseri ve sanat tekniği ile ilgili mesaj verilmeye çalışı1mıştır.

Tablo 5. Mati ve Dada ile Sanat Çizgi Filminde Çocuklara ve Öğretmenlere Yönelik Verilen Mesajlar

\begin{tabular}{|c|c|c|c|c|c|c|c|}
\hline & & \multicolumn{2}{|c|}{ Evet } & \multicolumn{2}{|c|}{ Hayır } & \multicolumn{2}{|c|}{ Kismen } \\
\hline & & $f$ & $\%$ & $f$ & $\%$ & $f$ & $\%$ \\
\hline \multirow[t]{5}{*}{$\begin{array}{l}\text { E-Verilen } \\
\text { Mesajlar }\end{array}$} & $\begin{array}{l}\text { Çizgi filmde çocuklara kendilerini sanat alanında geliştirmeleri } \\
\text { konusunda mesajlar verilmiştir. }\end{array}$ & 3 & 10 & 0 & 0 & 27 & 90 \\
\hline & Çizgi filmde karakterler çocuklara doğrudan mesajlar verir. & 2 & 6.7 & 8 & 26.7 & 20 & 66.7 \\
\hline & $\begin{array}{l}\text { Çizgi filmde karakterler arası diyaloglarda çocuklara dolaylı } \\
\text { yoldan mesajlar verilir. }\end{array}$ & 1 & 3.3 & 0 & 0 & 29 & 96.7 \\
\hline & Çizgi filmde öğretmenlere yönelik mesajlar bulunur. & 0 & 0 & 30 & 100 & 0 & 0 \\
\hline & $\begin{array}{l}\text { Çizgi filmde karakterler arası diyaloglarda öğretmenlere } \\
\text { dolaylı yoldan öneride bulunulmuştur. }\end{array}$ & 0 & & 30 & 100 & 0 & 0 \\
\hline
\end{tabular}




\section{Tartışma ve Sonuç}

Yapılan analizler sonucunda elde edilen bulgular, biçimsel özellikler, sanat ve sanatçı, kültürel ögeler, gelişimsel uygunluk özellikleri ve verilen mesajlar doğrultusunda incelenmiştir.

Mati ve Dada ile Sanat çizgi filmi incelendiğinde biçimsel özelliklerin genel olarak çocukların gelişimsel seviyelerine uygun olduğu gözlemlenmiştir. Çizgi filmde kullanılan dil açık ve anlaşılır bulunmuştur. Buna ek olarak, çizgi filmde anlatım bozukluğuna rastlanmaması, kullanılan dilde telaffuz hatalarının olmaması ve ayrıca kullanılan kelimelerin günlük dilde de kısmen rastlanabilir olması sebebiyle, Mati ve Dada ile Sanat çizgi filminin anlatım yönünden çocukların gelişimsel seviyelerine uygun olduğu söylenebilir. Ancak, ilgili çizgi film sınıfta bir öğretim materyali olarak kullanıldığında, öğretmenin yeni ortaya çıkan kelimeleri açıklayarak çocuklara destek olması gerektiği düşünülmektedir. Örneğin, Horiu Ji Tapınağı bölümünde geçen 'Antik Japon' kelimesi veya Canaletto bölümünde geçen 'eskiz, başyapıt' kelimeleri, çocuklar için karmaşa yaratacak bir nitelikte olabilir. Öğretmenin, bu konuda açıklamalarda bulunması ve gerekli gördüğü yerde ilgili kavramı/kelimeyi anlatmak üzere aktiviteler tasarlaması gerekebilir. Bu sayede Mati ve Dada ile Sanat çizgi filminin aynı zamanda çocuğun dil gelişimine de katkı sağlayacak nitelikte olacağı ve ayrıca çocuğun kelime dağarcığının gelişmesine de katkıda bulunacağına inanılmaktadır. Çizgi filmlerin çocukların kelime dağarcığını geliştirmede pozitif etkileri olduğunu ortaya koyan çalışmalar bulunmaktadır (Beştaş ve Şahin, 2011; Karataş ve Sarıçoban, 2011). Bu nedenle, Mati ve Dada ile Sanat çizgi filminin sanat ve dil entegre etkinliklerinde kullanılmasının hem çocukların kelime dağarcığının gelişmesine hem de sanatsal kavramları tanımalarına katkıda bulunacağı düşünülmektedir.

Çizgi filmin süresi sanatçı ve eseri hakkında yeterli bilgiyi vermek için uygundur. Ancak, bulgulardan çıkan sonuçlara bakılarak, çizgi filmde verilen bilgilerin çocuklar tarafından anlaşılması için ön bilgiye ihtiyaç duyulduğu söylenebilir. Yapılandırmacı yaklaşıma göre öğrenme, yeni bilgilerin, eskilerin üstüne inşa edildiği aktif bir süreçtir (Naylor ve Keogh, 1999). Bu nedenle, sinıflarında bu çizgi filmi kullanacak alan öğretmenler öncül etkinliklerle çocukları desteklemelidir. Örneğin, kitap okuma etkinliği, konusu geçen kişinin tanıtıldığı dil etkinlikleri veya temsili görsellerle tanıtım etkinlikleri gerçekleştirilebilir. Bergamalı Apollodorus ve Panteon Tapınağı bölümünde Eski Roma ve imparator kavramları kullanılmıştır. Çocuk tarafından algılanması zor olabilecek kavramların, çeşitli görseller ve açıklayıcı bilgilerle desteklenerek öncül etkinliklerin gerçekleştirilmesi uygun olacaktır. Paylaşılacak olan ön bilgiler ve öncül etkinliklerin, çocuğun bahsedilen sanatçıya olan 
hâkimiyetini arttıracağı düşünülmektedir. Ayrıca, çizgi filmde yer alan sanatçının görsel imajı veya temsili sanatçının gerçek imajına benzemektedir. Bahsi geçen eserlerin ve sanatçıların, gerçek imajlarına ve eserlerinin aslına benzemesi; çocuklarda sanat kültürü edinimi oluşturarak, günlük hayatta karşıladıklarında sanatçıyı ve eserini tanımalarını sağlayacaktır (Berk, 2013). Çocukların gündelik hayatlarında bile bu kavramları ve kişileri tanıyor olmaları, onların hem sanat algılarını geliştirecek, hem de öğretmenin sınıfta daha karmaşık yapılarda etkinlikler uygulamasına olanak tanıyacaktır.

Okul öncesi dönem, çocukların kelime dağarcığının hızlı geliştiği bir dönemdir (Berk, 2000). Bu açıdan bakıldığı zaman, Mati ve Dada ile Sanat çizgi filminin içerisinde yoğun olarak sanat terminolojisi barındırması, sanatçının sanat tarzı hakkında bilgi vermesi ve sanatçının kullandığı farklı yöntemleri tanıtıyor olması, çocukların zihinlerini en aktif kullandıkları dönemlerden biri olan okul öncesi çağında, onların bilişsel ve dil becerilerine katkıda bulunacağı söylenebilir. Ancak, öğrenilen tüm bu yeni kavramların tekrar yoluyla pekiştirilmesi gerekmektedir. Okul öncesi dönem çocuklarının hızlı gelişimlerini yakalamak ve kazanımlarının pekiştirilip kalıcılığını sağlamak için öğrenmenin birikimli bir süreç içerisinde gerçekleşmesi gerektiği, eğitim programının temel özelliklerinden biri olan "sarmaldır" özelliğinde de vurgulanmaktadır (MEB, 2013). Bu noktada öğrenilen terminolojilerin öğretmen tarafından farklı etkinlikler içerisinde de kullanılıyor ve tekrar ele alınıyor olması gerekecektir.

Çizgi filmde sanatçının yaşadığı yerin-ülkenin özelliklerinin yeterince vurgulanmadığı belirlenmiştir. Sanat ve kültür ayrı düşünülemeyecek iki unsurdur. Çizgi filmler de kültür aktarımında eğitici bir unsur olarak karşımıza çıkar (Özer ve Bozkurt-Avcı, 2015). Bunun yanı sıra, sanatçının yaşadığı yer hakkında bilgi verilmesi ve sanatçının sanatı hakkında çocukların neden sonuç ilişkisi kurmasına yardımcı olabilir. Bu nedenle, öğretmenler sınıflarında, ilgili bölümde tanıtılan sanatçının yaşadığı ülke ve kültür hakkında çocukları destekleyecek etkinlikler gerçekleştirmelidir. Örneğin, Henri Matisse'in tanıtıldığı bölümden önce veya sonra Fransa ile ilgili etkinlikler yapılabilir, izlenen bölüm ile tanıtılan ülke hakkında bağlantılar kurularak çocukların öğrenme süreci pekiştirilebilir.

Kültür öğrenme ortamının vazgeçilemez bir parçasıdır. Çocukların içinde bulunduğu kültür, onların bakış açısını doğrudan etkileyen bir unsurdur. $\mathrm{Bu}$ da onların öğrenme ortamlarının içerisinde bulundukları kültüre göre öz düzenlenme yapmalarını gerektirecektir (Arnove ve Torres, 2003). Ancak, çocukların erken yaşlarda çok kültürlülük kavramı ile tanıştırılması onların hem vizyonunu geliştirecek hem de bakış açılarını genişletecektir (Gregory, Long ve Volk, 2004). Ayrıca, okul öncesi eğitim programında yer alan kazanım ve 
göstergelerde çocukların farklı kültürleri tanımalarının önemine vurgu yapılmıştır (MEB, 2013). Tüm bu sebepler göz önünde bulundurulduğunda, Mati ve Dada ile Sanat çizgi filminin çocuklara yeni bir kültür tanıtmada başlangıç etkinliği olarak kullanılmasının uygun olabileceği düşünülmektedir. Çizgi film içerisinde sanatçıların gerçek hayattaki dil ve aksanlarının yansıtılmış olması ve sanatçının yaşadığı dönemin giyim kuşam özelliklerinin çizgi filme yansıtılmış olması çocukların farklı kültürleri tanımaları için bir başlangıç adımı sayılabilecek niteliktedir.

Araştırmalara göre çocuklar 5-7 yaşlarında dikkatlerini 15 dakika süreyle devam ettirebilmektedirler (MEB, 2005). Buna göre çizgi filmin süresinin okul öncesi çağ1 çocuklarının gelişimsel seviyelerine uygun olduğu söylenebilir. Bu da çizgi filmin etkinlikler sırasında kullanımını kolaylaştıracaktır. Öğretmen sanat etkinliğine başlamadan önce veya başladıktan sonra etkinliğin on dakikasını çizgi filme ayırabilir. Çizgi filmin süresinin uygun olması çizgi filmi ayrı bir etkinlik olarak kullanmaktansa ana etkinliğin bir materyali olarak kullanabilmeye imkân tanımaktadır.

Mati ve Dada ile Sanat çizgi filmi birçok soyut kavram içermektedir. Soyut kavramları anlamak okul öncesi çağı çocukları için zorluk teşkil edebilmektedir. Bu nedenle öğretmenler, videoda geçen soyut kavramları, çocukların yaşamları ve yakın çevreleriyle ilişkilendirebilecekleri durumlardan yararlanarak, çocuklar için somut hale getirebilecek etkinlikler planlamalıdırlar (MEB, 2013). Örneğin; Amedeo Modigliani isimli ressam ve heykeltıraşın tanıtıldığı bölümde, ressamın, "Ben gözlerimizin hem dış dünyayı gördüğüne hem de içimizi gördüğüne inanırım çocuklar." cümlesinin çocuklar için soyut kalacağı ve öğretmenin açıklamasına ihtiyaç duyulacağı düşünülmektedir. Bu durumda, öğretmenin önce çocuklar için bu cümlenin ne anlam ifade ettiğini araştıracak sorular sorması, daha sonra gerekli gördüğü açıklamalarla çocukları desteklemesi önerilebilir.

Bulgulara bakıldığında çizgi filmde çocuklara kısmen, doğrudan ve dolaylı olarak mesajlar verildiği görülmektedir. Bulgular kısmında örnekleri yer alan mesajlar da göz önünde bulundurulduğunda, çizgi filmde çocuklarda sanat kültürü oluşturmak amaçlandiğı, bu amaç doğrultusunda hedef kitlesinin çocuklar olduğu sonucuna ulaşılmıştır. Mati ve Dada ile Sanat çizgi filminin sanat etkinliklerinde kullanılmasının uygun olup olmadığına bakıldığı bu çalışmada, çizgi filmin öğretmenlere yönelik doğrudan veya dolaylı hiçbir mesaj içermediği gözlemlenmiştir. Dolayısıyla öğretmenler çizgi filmin bölümlerini inceleyerek, kendi öğrencilerinin ihtiyaç ve ilgilerine göre etkinliklerine dâhil edebilirler. Örneğin sınıfında renkleri karıştırmaya ilgi duyan çocuklar bulunan bir öğretmen, Mati ve Dada ile Sanat çizgi 
filminin “Jackson Pollock” bölümünden yararlanarak çocuklara, onun gibi resim yapmaları için firsatlar sunabilir. Böylece çocuklar renkleri keşfederken aynı zamanda Jackson Pollock isimli sanatçıyı ve onun resim tarzını tanıyabilirler.

\section{Makalenin Bilimdeki Konumu}

Temel Eğitim/Okul Öncesi Öğretmenliği

\section{Makalenin Bilimdeki Özgünlüğü}

Mevcut çalışmada Mati ve Dada ile Sanat çizgi filminin okul öncesi kurumlarında uygulanan sanat etkinliklerinde kullanımının uygunluğu araştırılmıştır. Milli Eğitim Bakanlığı Okul Öncesi Eğitim Programı'nda belirtildiği üzere, okul öncesi dönemde çocukların sanat eserlerini gözlemleyebileceği, sanat eserinin değerini fark edebileceği, sanat eseri ile ilgili düşüncelerini paylaşabileceği ve farklı sanat dalları ile ilgili deneyimler kazanabileceği firsatlar sunulmalıdır (MEB, 2013). Teknoloji araçlarının eğitime entegrasyonu da dijital çağ çocuklarına ulaşmak için önemli bir adımdır. Araştırma sonuçlarının, okul öncesi öğretmenlerinin sanat etkinliklerine Mati ve Dada ile Sanat çizgi filmini dahil ederek daha zengin içerikli ve ilgi çekici uygulamalarda bulunabilmelerine katkı sağlayacağı düşünülmektedir.

\section{Kaynaklar}

Acer, D. (2015). Okul öncesi dönem çocuklarının sanat hakkındaki düşünceleri: 'Çocuk sanatç1-sanatçı çocuk' projesi. Kastamonu Education Journal, 23(4), 1679-1694.

Akça, F. ve Çilekçiler, N. K. (2019). The cartoon characters with the greatest influence on preschool children and the digital dangers they can be exposed to while identifying with these characters. Addicta: The Turkish Journal of Addictions, 6(2), 403-433.

Akgün, E., Y1lmaz, E. O. ve Seferoğlu, S. S. (2011). Vizyon 2023 strateji belgesi ve firsatları artırma ve teknolojiyi iyileştirme hareketi (FATİH) projesi: Karşılaştırmalı bir inceleme. Akademik Bilişim, 2(4), 115-122.

Arnove, R. F. ve Torres, C. A. (2003). Comparative education: The dialectic of the global and the local (6th Ed.). Lanham: Rowman \& Littlefield.

Athanasiadis, I., Persa, F., Ilias, A. ve Efstathios, S. (2011). Teaching art using technology: The views of high school students in Greece. Review of European Studies, 3(2), 98-109.

Ayan, S. ve Baş, B. (2015). Çizgi filmler ile ilkokul öğrencilerinin söz varlı̆̆ üzerine bir araştırma. Ana Dili Ĕgitimi Dergisi, 3(4), 84-99. 
Ayman-Nolley, S. (1999). A Piagetian perspective on the dialectic process of creativity. Creativity Research Journal, 12(4), 267-275.

Bakeman, R. ve Gottman, J. M. (1997). Observing interaction: introduction to sequential analysis (2n Ed.). Cambridge: Cambridge University Press.

Beştaş, M. ve Şahin, S. (2011). Çizgi filmlerde atasözü ve deyimlerin kullanımı. S. Sever ve diğerleri (Ed.), Ankara Üniversitesi Çocuk ve Gençlik Edebiyatı Uygulama ve Araştırma Merkezi (ÇOGEM) 3. Ulusal Çocuk ve Gençlik Edebiyatı Sempozyumu içinde (s. 595606). Ankara Üniversitesi Basımevi: Ankara. Erişim adresi http://cogem.ankara.edu.tr/wp-content/uploads/sites/311/2016/12/3ucgs-2.pdf.

Berk, L. E. (2000). Bebekler ve çocuklar. (7. Baskıdan Çeviri). Ankara: Nobel Yayınları

Berk, L. E. (2013). Child development ( 9th Ed.). Boston: Pearson Education.

Black, J. ve Browning, K. (2011). Creativity in digital art education teaching practices. Art Education, 64(5), 19-34.

Cesur, S. ve Paker, O. (2007). Televizyon ve çocuk: Çocukların tv programlarına ilişkin tercihleri. Elektronik Sosyal Bilimler Dergisi, 19(19), 106-125.

Couse, L. J. ve Chen, D. W. (2010). A tablet computer for young children? Exploring its viability for early childhood education. Journal of Research on Technology in Education, 43(1), 75-96.

Denzin, N. K. ve Lincoln, Y. S. (2005). The Sage handbook of qualitative research. Thousand Oaks, California: Sage.

Glesne, C. (2012). Becoming Qualitative Researchers (4th Ed.), Pearson: Boston.

Gregory, E., Long, S. ve Volk, D. (2004). Many pathways to literacy: Young children learning with siblings, grandparents, peers and communities. Routledge: New York.

Güler, T. ve Akman, B. (2006). 6 Yaş çocuklarının bilim ve bilim insanı hakkındaki görüşleri. Hacettepe Üniversitesi Eğitim Fakültesi Dergisi, 31(31), 55-66.

Huang, Y., Li, H. ve Fong, R. (2016). Using augmented reality in early art education: A case study in Hong Kong kindergarten. Early Child Development and Care, 186(6), 879-894.

İbili, E. ve Şahin, S. (2016). The use of cartoons in elementary classrooms: An analysis of teachers' behavioral intention in terms of gender. Educational Research and Reviews, 11(8), 508-615.

Jukes, I., McCain, T. ve Crockett, L. (2010). Understanding the digital generation: Teaching and learning in the new digital landscape. Thousand Oaks, CA: Corwin Press 
YYÜ Eğitim Fakültesi Dergisi (YYU Journal of Education Faculty), 2021;18(2)664-690,http://efdergi.yyu.edu.tr,

Karakaş, A. ve Sarıçoban, A. (2011). Altyazllı çizgi filmlerin öğrencilerin tesadüfì kelime ögrenimleri üzerine etkileri. 20. Ulusal Eğitim Bilimleri Kurultayında sunulan bildiri. Mehmet Akif Ersoy Üniversitesi, Burdur. Erişim adresi https://www.pegem.net/akademi/kongrebildiri_detay.aspx?id=125612.

Kivunja, C. (2014). Theoretical perspectives of how digital natives learn. International Journal of Higher Education, 3(1), 94-109.

Madanipour, P. ve Cohrssen, C. (2020). Augmented reality as a form of digital technology in early childhood education. Australasian Journal of Early Childhood, 45(1), 5-13.

Marner, A. (2013). Digital media embedded in Swedish art education-a case study. Education Inquiry, 4(2), 355-373.

Milli Eğitim Bakanlığı (t.y.). FATïH projesi hakkında. Erişim adresi: http://fatihprojesi.meb.gov.tr/proje-hakkinda/ sayfasından erişilmiştir.

Milli Eğitim Bakanlığı (2005). Dikkat eksikliği ve hiperaktivite/aşırı hareketlilik bozukluğu olan çocukların eğitiminde öğretmen el kitabı. Erişim adresi: https://orgm.meb.gov.tr/kitaplar/Dikkat_eksikligi_egitiminde_ogretmen_el_kitabi.pdf.

Milli Eğitim Bakanlığı (2013). Okul Öncesi Eğitim Genel Müdürlüğü Okul Öncesi Eğitim Programı (36-72 Aylık Çocuklar Iç̧in). T. Gürkan ve G. Haktanır (Ed.) Ankara: MEB Yayınları.

McClure, M., Tarr, P., Thompson, C. M. ve Eckhoff, A. (2017). Defining quality in visual art education for young children: Building on the position statement of the Early Childhood Art Educators. Arts Education Policy Review, 118(3), 154-163.

Morrison, G. S. (2007). Early childhood education today (10th Ed.), New Jersey: Pearson Education.

Naylor, S. ve Keogh, B. (1999). Constructivism in classroom: Theory into practice. Journal of Science Teacher Education, 10(2), 93-106.

Oliemat, E., Ihmeideh, F. ve Alkhawaldeh, M. (2018). The use of touch-screen tablets in early childhood: Children's knowledge, skills, and attitudes towards tablet technology. Children and Youth Services Review, 88, 591- 597.

Oruç, C., Tecim, E. ve Özyürek, H. (2011). Okul öncesi dönem çocuğunun kişilik gelişiminde rol modellik ve çizgi filmler. Ekev Akademi Dergisi, 15(48), 281-297.

Oyero, O. ve Oyesomi, K. O. (2014). Perceived influence of television cartoons on Nigerian children’s social behaviour. Estudos em Comunicação, 17, 91-116. 
Özer, D. ve Bozkurt-Avc1, İ. (2015). Cartoons as educational tools and the presentation of cultural differences via cartoons. Procedia-Social and Behavioral Sciences, 191, 418423.

Partnership For 21st Century Skills (P21) (t.y.). Framework for21st Century Learning. Erişim adresi: http://www.p21.org/about-us/p21-framework

Pellerin, M. (2012). E-inclusion in early French immersion classrooms: Using digital technologies to support inclusive practices that meet the needs of all learners. Canadian Journal of Education, 36(1), 27.

Resnick, M. (2007). All I really need to know (about creative thinking) I learned (by studying how children learn) in kindergarten. Proceedings of the 6th ACM SIGCHI conference on Creativity \& cognition, 1-6.

Rideout, V. J., Vandewater, E. A. ve Wartella, E. A. (2003). Zero to six: Electronic media in the lives of infants, toddlers and preschoolers. Erişim adresi: https://kaiserfamilyfoundation.files.wordpress.com/2013/01/zero-to-six-electronicmedia-in-the-lives-of-infants-toddlers-and-preschoolers-pdf.pdf.

Sayan, H. (2016). Okul öncesi eğitimde teknoloji kullanımı. 21. Yüzyılda Eğitim ve Toplum Ĕ̌itim Bilimleri ve Sosyal Araştırmalar Dergisi, 5(13), 67-83.

Terreni, L. (2010). Adding new possibilities for visual art education in early childhood settings: The Potential of Interactive Whiteboards and ICT. Australasian Journal of Early Childhood, 35(4), 90.

Trimis, E. ve Savva, A. (2004). The in-depth studio approach: Incorporating an art museum program into a pre-primary classroom. Art Education, 57(6), 20-34.

Vygotsky, L. S. (2004). Imagination and creativity in childhood. Journal of Russian \& East European Psychology, 42(1), 7-97.

Yağl1, A. (2013). Çocuğun eğitiminde ve sosyal gelişiminde çizgi filmlerin rolü: Caillou ve Pepee örneği. Electronic Turkish Studies, 8(10), 707-719.

Yenilik ve Eğitim Teknolojileri Genel Müdürlüğü (2020). Eğitim Bilişim Ă̆l (EBA). https://www.eba.gov.tr/ sayfasından erişilmiştir.

Yıldırım, A. ve Şimşek, H. (2000). Sosyal Bilimlerde Nitel Araştırma Yöntemleri (2. Baskı). Ankara: Seçkin Yayıncılık. 


\section{Summary \\ Statement of Problem}

Within the current technology era, creativity and productivity are among the most important skills that individuals need to have and developmentally take their roots in early childhood period. Experience and environmental factors are considered crucial in contributing creativity and productivity. Consequently, appropriate environment, materials and opportunities should be provided to children in early childhood period (Milli Eğitim Bakanlığ [MEB], 2013). Specific to art activities, presentation of materials for contributing aesthetic perception and skills, motivating children to produce original products are suggested practices of the national early childhood education program (MEB, 2013). While practices that nourish children's creativity through experience become widespread, presenting artists and art products to children within their natural learning environment come into prominence (Acer, 2015; Trimis and Savva, 2004). Introducing children with museums, artists and art products enable them to discover various experiences and enrich their inner worlds.

By considering current century's conditions, technology and art cannot be considered independent from each other. Integrating art with technology is crucial in means of contributing learning, imagination and creativity in children (Black and Browning, 2011; Huang, Li and Fong, 2016; Marner, 2013; Terreni, 2010). Literature review revealed that, there is considerable literature on technology use in early childhood, technology integration in art education and media in early childhood, while there is a limited research on the use of cartoon in art activities in early childhood education. Therefore, there is a need to study the current issue to fill this gap.

\section{Purpose of the Study}

This study aimed to investigate the use of Art with Mati and Dada cartoon series in art activities for introducing artist and art product to children within the context of early childhood education. In the direction of this aim, the following research questions were asked;

1) What are the structural characteristics of Art with Mati and Dada cartoon series?

2) What are the artists and art characteristics depicted in Art with Mati and Dada cartoon series?

3) What are the cultural elements depicted in Mati and Dada cartoon series?

4) What are the developmental characteristics depicted in Art with Mati and Dada cartoon series? 
5) What are the messages given to children and teachers in the Art with Mati and Dada cartoon series?

\section{Method}

This research followed qualitative research methodology utilizing a descriptive study design. Document analysis (Yıldırım and Şimşek, 2000) was used in the study and each episode of the "Art with Mati and Dada” cartoon was accepted as a unique document for the analysis. 39 episodes of the Mati and Dada cartoon has been broadcasted through internet were the target population while the sample consists of 30 episodes of the cartoon translated in Turkish.

In order to obtain data from the Art with Mati and Dada cartoon, a coding list (evaluation manual) was created. Expert opinions were gathered from academician from art education, early childhood education and children's media. In the final form, there are 37 questions with 3 categories (Yes/No/Partial). Inter-coder reliability between researchers was found as 98\% (Bakeman \& Gottman, 1997).

\section{Findings}

Analyses showed that, the language and the sentences used in the cartoon are clear and understandable ( $n=21)$ and the duration of the series are appropriate for passing along the information related with artist and art product $(n=20)$. When we consider the characteristics of artist and art product in the cartoon series, most of the cartoons $(n=19)$ need to be supported by the necessary prior knowledge in order for children to comprehend the information. Moreover, in all of the cartoon series $(n=30)$, visual image of the artist and the art product resemble the real images of them. In addition, in most of the cartoon series $(n=22)$, information on artistry terminology and way of art was given place. In a similar way, in most of the cartoon series ( $n=24)$, methods used by the artist in the production of art product was also displayed. Almost in half of the cartoon series $(n=14)$, the country or the living place of the artist has been emphasized partially whereas, $86.7 \%$ of the cartoons are partially representing living conditions of artists. In addition, while $43.3 \%$ of the cartoons are giving place to connection between different branches of art, these connections have been represented partially in $23.3 \%$ of the cartoons.

In most of the cartoons ( $n=26)$, the apparel style of the period that the artist was living in was reflected through the drawing of the clothing. Besides, style of pronunciation/accent used in the living place of artist was reflected partially to the $26.7 \%$ of the $n=27$ ) the cartoon series. Besides developmental characteristics, when the series were investigated for their messages given for the teachers and children, neither of them were determined as giving direct 
YYÜ Eğitim Fakültesi Dergisi (YYU Journal of Education Faculty), 2021;18(2)664-690,http://efdergi.yyu.edu.tr,

or indirect messages but partially giving direct messages (66.7\%) and partially giving indirect messages (96.7\%).

\section{Discussion and Conclusion}

Study results indicated that, prior knowledge related with art concepts are necessary for children to understand the concepts mentioned in most of the cartoon series. According to constructivist approach, learning is an active process in which new information is built upon old knowledge (Naylor \& Keogh, 1999). Therefore, art activities with the presence of Art with Mati and Dada cartoon should be supported by teachers with antecedent activities. Moreover, using Mati and Dada cartoons in art activities in the early childhood context would be a supporter element in contributing children's vocabulary and knowledge in art concepts. Teachers can use Art with Mati and Dada cartoon as a supporter component and by providing prior knowledge; they can use the series as a part of art activities. Besides those gains, introducing multiculturalism through the use of cartoon to children will develop children's vision and expand their viewpoint (Gregory, Long \& Volk, 2004). 